\title{
Pattern of Biogas Production and Removal of Chemical Oxygen Demand in Semi Continues Hybrid Anaerobic Reactor
}

\author{
N.I. Oktavitri ${ }^{1}$, A. Soegianto ${ }^{1}$, T. Rahman ${ }^{2}$, B. Saadah ${ }^{1}$, and D. Trianingtyas ${ }^{1}$
}

\begin{abstract}
Anaerobic process had been used for treated highly organic substances, such as canteen wastewater which had COD around $5000 \mathrm{mg} / \mathrm{L}$. This research aims to investigate pattern of biogas production and COD removal in semi continue anaerobic process. HRT (Hydraulic Retention Times) were used in this research 1,5 hours. The reactor was contained of four cell coulombs from PVC, with height 1 meter. Gravel as media support in hybrid anaerobic reactor. The height of media support is $50 \mathrm{~cm}$. This reactor operated for 14 days. Parameters had been observed are biogas production and COD.. Biogas production after reactor operated 7 days $0,6594 \mathrm{~mL}$ and after reactor operated 14 days is $1,4758 \mathrm{~mL}$. COD removals are $38,89 \mathrm{mg} / \mathrm{L}$ after operated 7 days and 42,86 mg/L after operated 14 days. In conclusion, COD removal increased after reactor operated 7 and 14 days. The biogas production increased after 7 and 14 operated days. Increasing of biogas production more drastically than COD removal.
\end{abstract}

Keywords_ - biogas production; COD removal; canteen wastewater, hydraulic retention time.

\section{INTRODUCTION}

$\mathrm{O}$ ne of type of domestic wastewater is canteen wastewater. Canteen wastewater produces from washing dishes. Canteen wastewater, household wastewater, restaurant wastewater has highly organic substance (Apriyadi, 2008). In other side, the high organic substance can influence aquatic biota. Therefore it need to be treated canteen wastewater.

Advances in anaerobic treatment of domestic wastewater offer a few promising options including Up flow Anaerobic Sludge Blanket (UASB), Anaerobic Filter (AF), Anaerobic Baffled Reactor (ABR), Hybrid Reactor (HR). It is reported that most of the negative aspects of high rate anaerobic reactors can be overcome by restricting the supported material to the top 25 to $30 \%$ of the reactor volume. This would help realize the advantages of both fixed film and up flow sludge blanket treatment. This kind of reactor is called Hybrid Up flow Anaerobic Sludge Blanket (HUASB) and is considered more stable for the treatment of a series of soluble or partially soluble wastewaters. Over the years, HUASBs have been used to treat a variety of industrial effluents. In the present study, HUASB has been used to treat domestic wastewater.

Hybrid reactors are developed as advancement to the UASB reactor by incorporating some modification into UASB reactor from other single-stage reactors. In these reactors biomass of bacteria is allowed to attach to inert film apart from suspended flocs or granules. Thus the biomass held in all over the reactor reduces the pollution load of substrates.

The ability of HUASB to decrease of organic substance it also depends to agitation in HUASB. Agitation has many function to made potential microbes has opportunity to blend with organic substance and decrease it. This research using hydraulic agitation in the HUASB

${ }^{1}$ N.I. Oktavitri, A. Soegianto, B. Saadah, and D. Trianingtyas are with Departement of Bilogy, Faculty of Environmental Science and Technology, Universitas Airlangga, Surabaya, Indonesia. E-mail: nur_i_d_o@yahoo.com.

${ }^{2} \mathrm{~T}$. Rahman is with Departement of Information System, Universitas Airlangga, Surabaya, Indonesia. system. The ability of decreased organic substance for every reactor system had differences. It was interesting to concern. Those abilitwas showed with decrease of Chemical Oxygen Demand (COD). The decrease of COD in anaerobic reactor will resulted biogas production. There is a specific pattern between COD reduction and biogas production in HUASB reactor. This research observed of it.

\section{METHOD}

Wastewater used in this research from canteen at Science and Technology Faculty, Airlangga University, Surabaya, JawaTimur. The canteen wastewater was collected from fresh canteen wastewater without any preliminary treatment.

\section{A. Material and Instrumentation}

The reactor is made from PVC pipe and acrylic. Diameter of the pipe is $15 \mathrm{~cm}$ and the height is $120 \mathrm{~cm}$. Every column has a valve for effluent. The sample material is waste water from canteen. The parameter was observed are COD, alkalinity, $\mathrm{pH}$, temperature, biogas production.

Biogas production observed with $U$ manometer wgich filled with water. The biogas production will pushed those water to show the volume of biogas production.

\section{B. Flowrate setting}

Flow rate setting is done by adjusting the valve. Flow rate variation is used around $0.3 \mathrm{ml} /$ minute.

\section{Seeding and Acclimatization}

Seeding is done by submerging the gravel with rumen's cow. It is diluted $1: 1$ in water. Seeding is conducted over two days. Acclimatization process was conducted over seven days. The process of acclimatization successful if the results exceed $50 \%$ removal.

\section{Running Reactor}

The reactor was run for a month. From the equalization basin, sewage flowed by pump to be processed in the reactor. Anaerobic bio filter reactor used. The reactor consists of four columns with up flow stream. Each 
column is given the gravel as high as $50 \mathrm{~cm}$ for biofilm attachment media (Figure 1).

Sampling was done on days 7, after completed acclimatization. Samples were taken at the point of influent, effluent, and effluent point of each column. Each sample were measure TSS, VSS, temperature, and $\mathrm{pH}$.

\section{RESULT AND DISCUSSION}

Experiment were operated for 14 days. The results showed that difference value between influent and effluent had happened in 0 days, COD decreased from $5360 \mathrm{mg} / \mathrm{L}$ to $3600 \mathrm{mg} / \mathrm{L}$. The removal efficiency in 0 day reach $32.84 \%$ (Figure 2 )

The ability to decreased COD had improved after increasing operation time of reactor. The COD efficiency increased to $38,89 \%$ in 7 days and $42,86 \%$ in 14 days (Figure 1). The increasing of removal efficiency showed that reactor had adapted with wastewater which inflow in HUASB system. The pattern of COD efficiency increasing after operation day also increased. The removal efficiency was bellowed from Banu et al (2007). Banu et al (2007) had COD removal efficiency around $75-80 \%$ with hydraulic retention as variable. The hydraulic retention time in Banu et al (2007) around 3,3 $-7,3$ hours. This research only1.5 hours.

The pattern of removal could be increased by increasing hydraulic retention. Hydraulic retention time could gave microbes time to decrease organic substance with 4 steps. Hydrolysis and acidogenesis; acetogenesis and methanogenesis (de Lemos Chernicharo, 2007). The 4 steps influenced COD removal and biogas production pattern in anaerobic system. The hydrolysis and acidogenesis steps would made HUASB in acid $\mathrm{pH}$ (below pH7). The first phase in the anaerobic reactor consist of hydrolysis of complex particulate material into simpler dissolved materials (smaller molecules), which can penetrate through the cell membrane by fementative bacteria. The hydrolysis phase occurred slowly in anaerobic condition and affected the degree and rate at which substrate hydrolysed (Lettinga et al, 1996 in de Lamos Chernicharo. 2007). . This steps resulted volatile fatty acid which made HUASB reactor system in acid $\mathrm{pH}$ except HUASB had alkalinity to buffered $\mathrm{pH}$ condition in reactor. The system which lack of alkalinity made reactor system in acid $\mathrm{pH}$.

The fermentative bacteria in second phase, acidogenesis, penetrate the substrate in their membrane to make it appropriate for acetogenic bacteriaThe third step, acetogenesis, also made $\mathrm{pH}$ in system in acid condition. This step, acetogenic bacteria oxidated the products generated in the acidogenic phase into a substrate appropriate for the methanogenic microorganism (de Lamos Chernicharo. 2007).

The hydraulic and acidogenesis steps made the differences alkalinity in influent and effluent (Figure 1). In 0 day, alkalinity decreased from 862,5 mg/L to 612,5 $\mathrm{mg} / \mathrm{L}$. In 7 days and 14 days indicated the similar process. The system consumed alkalinity to buffered system in $\mathrm{pH}$ closed in 7 . In 7 days and 14 days, the consumption alkalinity increased because hydrolysis and acidogenic steps resulted much volatile fatty acid in system (Banu et al, 2007). The resulted volatile fatty acid not only indicated that hydrolysis complex material in smaller molecules also increased COD removal which COD component was complex organic material. Therefore, the increased of operation time also increased capability system to removal COD.

The consumption of alkalinity made $\mathrm{pH}$ system increased to $\mathrm{pH}$ closed to 7 . Figure 4, resulted the effluent of HUASB had higher $\mathrm{pH}$ than influent. $\mathrm{pH}$ closed to 7 made methanogenic bacteria produced methan which indicated the increased of biogas. Biogas consisted $60-70 \%$ of methane (Gerardi, 2003). The increased of methanogenic production increased after reactor operated. This condition similar with $\mathrm{pH}$ value in effluent increased after 7 days operated.. Biogas production drastically increased in 7 days similar with increased of COD removal (Figure 3 and Figure 6). Accumulating biogas production after 14 days operated reached 1,4758 Ml. The biogas production from this research lower than Banu et al (2007) which had 3000$7000 \mathrm{~mL}$. The highly biogas production in Banu et al (2007) was caused by $\mathrm{pH}$ value of system in 7.5-8. The appropriate $\mathrm{pH}$ for methanogenic bacteria. De Lemos Chemicaro (2007) said that $\mathrm{pH}$ value had highly influence in anaerobic condition. The Gerardi (2003) said that appropriate $\mathrm{pH}$ for anaerobic system was 1500 $\mathrm{mg} / \mathrm{L}$. Gerardi (2003) added of chemical solution could increase $\mathrm{pH}$ value in system such as Natrium Carbonate $\left(\mathrm{Na}_{2} \mathrm{CO}_{3}\right)$ and Calcium Hydroxide $\left(\mathrm{Ca}(\mathrm{OH})_{2}\right)$.

\section{CONCLUSION}

In conclusion, COD removal increased after reactor operated 7 and 14 days. The biogas production increased after 7 and 14 operated days. Increasing of biogas production more drastically than COD removal.

\section{ACKNOWLEDGEMENT}

This research was funded with DIPA Airlangga University with number contract 001/UN3.6/KR\U/PPK/2013, 2 May 2013. This research was supported with solid team: Fandi Nufinda Rahman; Hairul Amin; Adelia Anju Asmara; Santini Ika R.; Rosvita Tri J.; Sofiyudin; Defananda.

\section{REFERENCES}

[1]. Apriadi, Tri, “Kombinasi Bakteridan Tumbuhan Air Sebagai Bioremediator Dalam Mereduksi Kandungan Bahan Organic Limbah Kantin” Fakultas Perikanan dan Ilmu Kelautan, IPB, 2008, pp. 1-2.

[2]. Banu, J. R.; Kuliappan, S.; Yeom, I. T. (2007). Treatment of Domestic Wastewater Using Upflow Anaerobic Sludge Blanket Reactor. Int. J. Environ. Sci., 4(3), 363-370.

[3]. de Lemos Chernicaro, C. A. (2007). Anaerobic Reactors. IWA Publishing. New York. 70-82

[4]. Gerardi, M. H. (2003)The Microbiology of Anaerobic Digester. Wiley Interscience. United States of America. 77-177. 


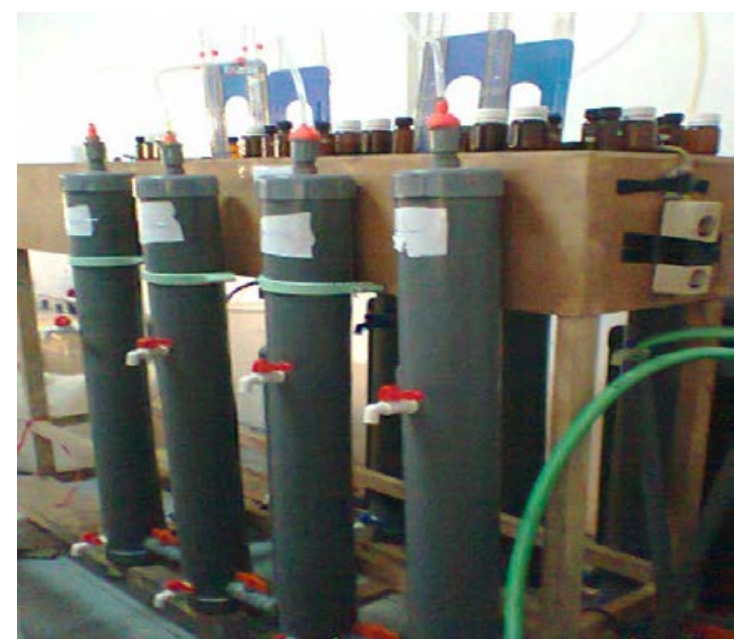

Figure 1. The picture of reactor

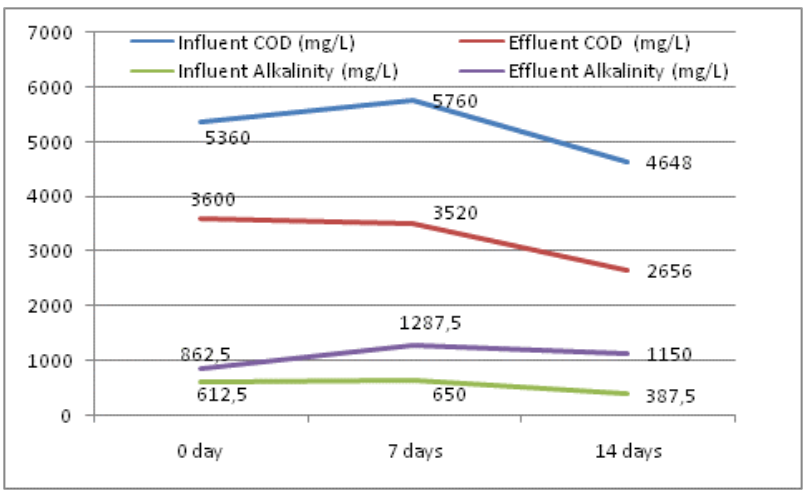

Figure 2. COD and Alkalinity concentration results

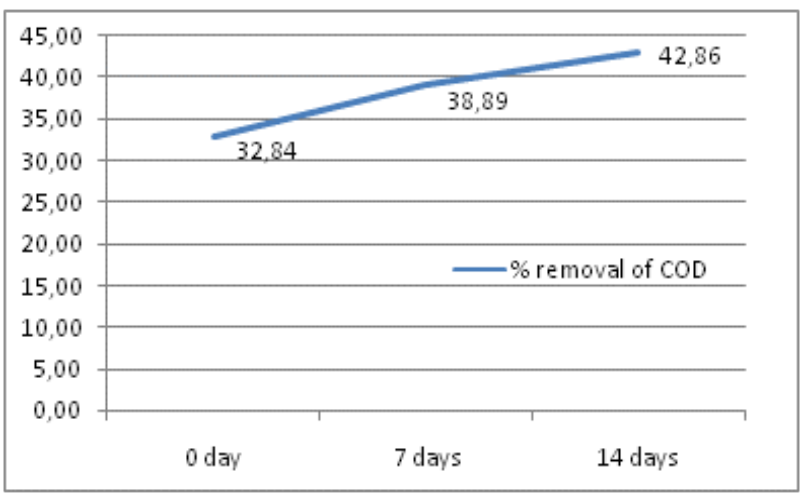

Figure 3. \% Removal of COD

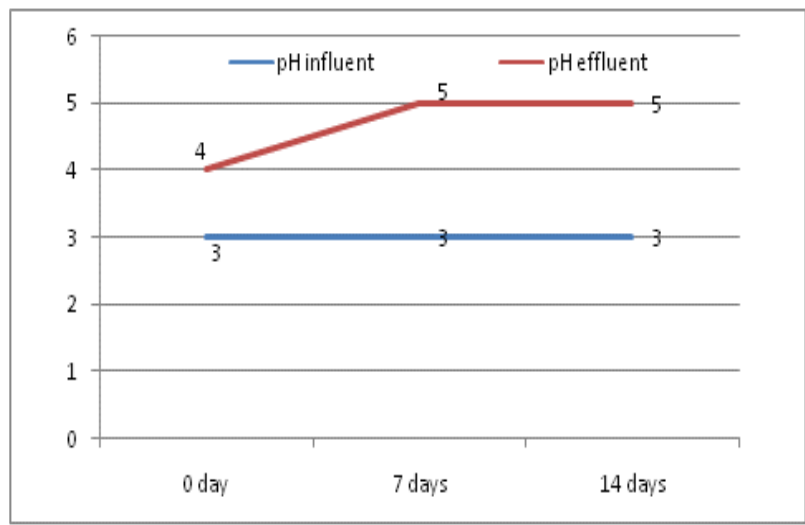

Figure 4. $\mathrm{pH}$ value in HUASB

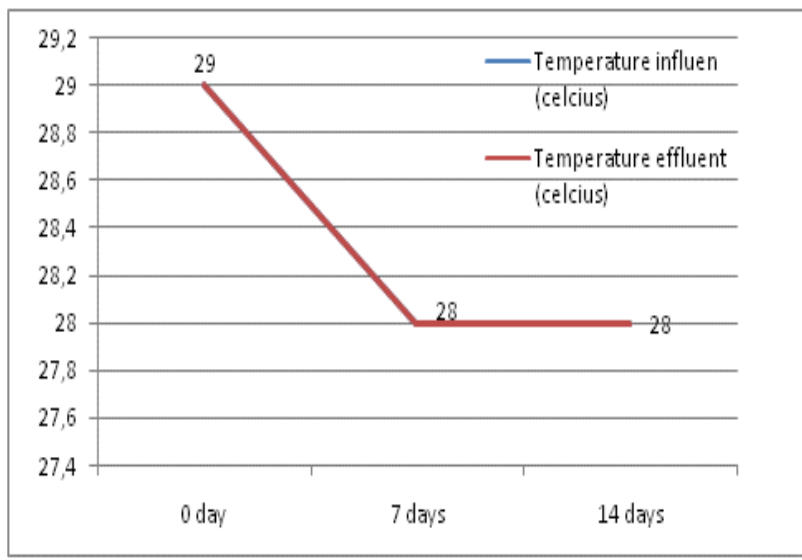

Figure 5 Temperature in HUASB

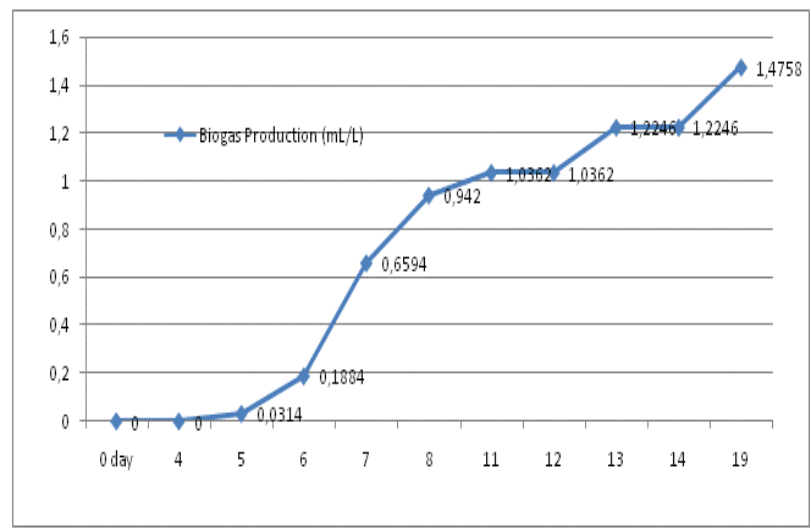

Figure 6. Biogas Production 